\title{
O retorno do autor e a representação do outro em os papéis do inglês e nove noites
}

\section{The return of the author and the representation of the other in os papéis do inglês and nove noites}

\section{El regreso del autor y la representación del otro en os papéis do inglês y nove noites}

\author{
(iD) Camila da Costa Fonseca \\ Universidade Federal de Pelotas (UFPEL), Pelotas, Rio Grande do Sul, Brasil. \\ E-mail: crc_pel@hotmail.com \\ iD) Alfeu Sparemberger \\ Universidade Federal de Pelotas (UFPEL), Pelotas, Rio Grande do Sul, Brasil. \\ E-mail: berger9889@gmail.com
}

\begin{abstract}
Resumo: Este artigo analisa a presença da figura autoral nas obras Os papéis do inglês (2007), de Ruy Duarte de Carvalho, e Nove noites (2006), de Bernardo Carvalho. Por meio de uma estratégia comparatista, apoiada nos postulados da antropologia pós-moderna, o lugar daquele que escreve e de sua linguagem na representação do outro, culturalmente diferente, é reconsiderado pela frequência do autor nos textos ficcionais, fato que aproxima ficção e não ficção.
\end{abstract}

Palavras-chave: Literatura e Etnografia. Autoria. Representação. Ruy Duarte de Carvalho. Bernardo Carvalho.

\begin{abstract}
This article analyzis the presence of the authorial figure in Ruy Duarte de Carvalho's Os papéis do inglês (2007) and in Bernardo Carvalho's Nove noites. Using a comparative approach, supported by postmodern anthropology premise, the place of whom writes and their language in
\end{abstract}


representing the other is reconsidered by the author's recurrence in the fictional texts, a factor that nears fiction than non-fiction.

Keywords: Literature and Etnography. Authorship. Representation. Ruy Duarte de Carvalho. Bernardo Carvalho.

Resumen: Este artículo hace un análisis de la presencia de la figura autoral en las obras Os papéis do inglês (2007), de Ruy Duarte de Carvalho, y Nove noites (2006), de Bernardo Carvalho. Por medio de una estrategia comparatista, apoyada en los postulados de la antropología posmoderna, el sitio de aquél que escribe y de su lenguaje en la representación del otro, culturalmente diferente, es reconsiderado por la frecuencia del autor en los textos ficcionales, hecho que aproxima ficción y no ficción.

Palabras clave: Literatura y Etnografía. Autoría. Representación. Ruy Duarte de Carvalho. Bernardo Carvalho.

Submetido em 18 de julho de 2020.

Aceito em 04 de setembro de 2020.

Publicado em 08 de fevereiro de 2021. 
O retorno do autor e a representação do outro em os papéis do inglês e nove noites Camila da Costa Fonseca - Alfeu Sparemberger

\section{Introdução}

As obras de Ruy Duarte de Carvalho e de Bernardo Carvalho encontram-se nas fronteiras entre ficção e realidade e possuem uma forte presença da figura autoral em suas construções. Dessa forma, estes textos estão relacionados com a Antropologia Pós-Moderna, com sua proposta de reconsiderar o lugar daquele que escreve e de sua linguagem na representação do outro, via de regra, considerado culturalmente diferente.

Na literatura contemporânea, o contato entre o artista e o outro reflete a convivência entre povos diferentes, quando se estabelecem relações muitas vezes conflituosas e desiguais. Tais relações são características de um movimento amplo, no quadro da "virada etnográfica", elemento presente em várias manifestações artísticas, como no cinema e na literatura.

No caso de Os papéis do inglês, desde cedo fica exposta a componente intertextual que dá origem à narrativa. A partir de uma crônica escrita por Henrique Galvão, o narrador discorre sobre como o inglês Sir Perkings matou seu parceiro de viagem, o Grego e, após entregar-se às autoridades e nada ser feito, retorna ao acampamento, destrói tudo o que há em volta e se suicida. O leitor recebe basicamente a narrativa da busca do narrador pelos papéis deixados pelo inglês. O narrador do livro é um antropólogo que explicita, em primeira pessoa, a forma de organização da narrativa, deixando claro que inventou boa parte do relato.

Em várias passagens, a identidade do narrador confunde-se com a do autor empírico, Ruy Duarte de Carvalho que, ao falar do personagem, acaba por falar de si, mesclando a demanda pelos papéis com a sua história pessoal. Nove noites, por sua vez, apresenta um narrador que relata suas andanças na busca por pistas sobre o suicídio do antropólogo americano Buell Quain, ocorrido em 1938, quando estava a caminho da cidade de Carolina. Essa demanda, uma busca "sem fim e circular" (CARVALHO, 2006, p. 37), é partilhada com um narrador secundário, Manoel Perna, confi- 
O retorno do autor e a representação do outro em os papéis do inglês e nove noites Camila da Costa Fonseca - Alfeu Sparemberger

dente do antropólogo, que registra as memórias das nove noites de convívio com o estudioso americano.

Essa presença do autor tornou-se mais frequente em narrativas contemporâneas, preocupadas com a representação da alteridade. Algumas dessas narrativas reconfiguram a subjetividade ao mesclar ficção e não ficção, apresentar uma linguagem que se desdobra sobre si mesma e, finalmente, por marcar uma forte presença da primeira pessoa, o que é característico daquilo que é chamado por Klinger (2012) de "retorno do autor".

Assim, o foco desta produção é a análise da presença autoral nas narrativas, discutindo a morte e o retorno do autor em dois textos ficcionais, quando reaparece não como o autor empírico, mas alguém que está presente na narrativa. Complementa o estudo uma análise dos romances de Ruy Duarte de Carvalho e de Bernardo Carvalho e da representação do outro nos moldes da etnografia pós-moderna.

\section{A desconstrução da categoria de sujeito}

Antes de explorar a reconfiguração da subjetividade contemporânea e o "retorno do autor", é importante compreender como se dá a desconstrução da categoria de sujeito. De acordo com Klinger (2012), essa desconstrução da categoria do sujeito teve seu início em Nietzsche, para quem o "eu" não é causa do pensamento, posto que este prescinde do eu.

As ideias de desconstrução propostas pelo filósofo alemão culminam com a declaração da morte do autor na literatura do século 20, conforme proposta elaborada por Michel Foucault. Segundo o filósofo francês, "Na escrita, não se trata da manifestação ou da exaltação do gesto de escrever; não se trata da amarração de um sujeito em uma linguagem; trata-se da abertura de um espaço onde o sujeito que escreve não para de desaparecer" (1992, p. 35).

Com esse desaparecimento do sujeito, que escreve Foucault, procura os espaços que ficam vazios e as funções que ficam evi- 
O retorno do autor e a representação do outro em os papéis do inglês e nove noites Camila da Costa Fonseca - Alfeu Sparemberger

dentes. O autor passa então a existir como "função", pois "não há fato humano que não seja estruturado, nem estrutura que não seja significativa, o que quer dizer, como qualidade do psiquismo e do comportamento de um sujeito, que não preencha uma função" (FOUCAULT, 1992, p. 75).

A "função autor", que substitui o autor para melhor situar a produção textual europeia no século 17, é "característica do modo de existência, de circulação e de funcionamento de alguns discursos no interior de uma sociedade" (FOUCAULT, 1992, p. 36). E possui quatro características: a primeira é a responsabilidade, que garantia a punição e também os méritos pelo conteúdo do que era produzido; a segunda está ligada a uma genealogia do texto, uma vez que é mais seguro atribuir valor a algo quando sabemos sua origem; a terceira é a construção do ser autor, como o lugar originário da escrita, o que teria um poder criador; e a quarta, e última, é a presença de um alter ego, pois nem tudo o que está escrito é exclusivamente do escritor para ele mesmo.

Segundo Klinger (2012), assim como os formalistas, o estruturalista francês Barthes também vai levar em consideração apenas a parte textual, desconfiando de tudo o que seja externo. Isso acontece com os gêneros que se utilizam da referencialidade de forma explícita e que dominantemente são marginalizados. A morte do autor se dá, se formos seguir os preceitos formalistas, no momento em que não há mais espaço para o escritor empírico.

Com a finalidade de confirmar essa "morte do autor", pode-se pensar na literatura como sendo criadora de uma nova realidade, e se algo de referencial é encontrado neste tipo de texto, é considerado uma literatura menor. A pura imitação da realidade não é vista como arte. Assim, para Herbert Marcuse,

A verdade da arte reside no seu poder de cindir o monopólio da realidade estabelecida (i.e., dos que a estabeleceram) para definir o que é real. Nesta ruptura, que é a formação estética, o mundo fictício da arte aparece como a verdadeira realidade. 
O retorno do autor e a representação do outro em os papéis do inglês e nove noites Camila da Costa Fonseca - Alfeu Sparemberger

A arte empenha-se na percepção do mundo que aliena os indivíduos da sua existência e actuação funcionais na sociedade - está comprometida numa emancipação da sensibilidade, da imaginação e da razão em todas as esferas da subjetividade e da objetividade (2007, p. 19, grifos do autor).

Mesmo que a literatura crie uma nova realidade e que isso tenha contribuído, de certa forma, para a chamada morte do autor, Foucault percebeu que a figura autoral havia deixado um espaço e o preencheu com a já citada função do autor. Isso manteve o autor empírico afastado dos estudos literários.

Barthes, por outro lado (e de acordo com Klinger), ainda que também aceite a tese da morte do autor, reconhece que ele está presente nas biografias dos escritores, nas entrevistas para os periódicos e na mídia como um todo. A preocupação dos estruturalistas era, portanto, ressaltar a autonomia da obra literária, impedindo que o autor fosse o fim último do texto, o que foi alcançado ignorando tudo o que fosse biográfico na análise literária. Segundo Klinger (2012), ao admitir a presença do autor em diversos veículos de comunicação, Barthes acaba suscitando a reflexão sobre a validade de uma leitura unicamente textual da literatura no século 21.

Diante da problematização da validade de uma leitura essencialmente textual nos dias atuais, ocorre o chamado "retorno do autor", quando a cultura de massas desperta nas pessoas a vontade de conhecer fatos reais e a figura do autor está presente na mídia, em entrevistas e em jornais. Em tal caso, já não é mais possível reduzi-lo a uma função. Pensando neste retorno do autor, é importante perguntar-se: que tipo de sujeito é este que retorna? Como podemos perceber nos textos de Ruy Duarte de Carvalho e Bernardo Carvalho, não é a figura do autor autobiográfico. Como fica, porém, a leitura de ficção depois disso? Vemos em Klinger que, 
O retorno do autor e a representação do outro em os papéis do inglês e nove noites Camila da Costa Fonseca - Alfeu Sparemberger

Segundo Hal Foster, o retorno do autor é uma virada significativa tanto na arte contemporânea, como na crítica, nas quais ele coincide com o "retorno do real". Na argumentação de Foster, o retorno do autor e o "retorno do real" não implicam nenhuma volta substancialista, uma vez que ele parte do conceito de "real" de J. Lacan, que o define como "aquilo que o sujeito está condenado a ter em falta, mas que essa falta mesma revela" (2012, p. 39).

A partir da necessidade do "retorno do real", começa a ganhar destaque o conceito de autoficção, uma vez que ele problematiza o choque entre a presença e a falta, e, também, a relação ou a mescla entre o real e o ficcional.

O conceito de autoficção surgiu com o escritor francês Serge Doubrovsky (2014), que, depois de ler o "Pacto Autobiográfico", de Philippe Lejeune, percebeu a fragilidade desta teoria, uma vez que não dá conta de todos os textos e ignora o fato de que existem narrativas dadas como autobiográficas pela identidade comum entre autor-narrador-protagonista, mas que apresentam dados referenciais mesclados à ficção, formando um romance.

Buscando preencher a lacuna deixada no conteúdo do chamado "pacto autobiográfico", Doubrosvky motivou-se a escrever, em 1977, Fils, romance em primeira pessoa, cujo narrador também se chama Serge Doubrovsky, e mostra "como autobiografia e romance podem coexistir em um mesmo texto" (2014, p. 121), surgindo o termo autoficção, que é definido pelo criador como "ficção, de fatos e acontecimentos estritamente reais" (2014, p. 120). A partir da autoficção o autor estaria transcendendo o espaço midiático e adentrando o terreno da ficção, na fronteira entre a realidade e a fantasia.

Assim, o autor, que retorna, aparece dentro e fora do texto. Este é, porém, diferente daquele autor "morto" pelos estruturalistas. De acordo com Klinger, "o autor retorna não como garantia última da verdade empírica e sim apenas como provocação, na forma de um jogo que brinca com a noção do sujeito real" (2012, 
O retorno do autor e a representação do outro em os papéis do inglês e nove noites Camila da Costa Fonseca - Alfeu Sparemberger

p. 47, grifos da autora). O autor contemporâneo passa então a ser responsável pela autoria do texto sem ser o detentor da verdade textual; ele regressa como alguém confuso entre o que pode ou não ser real, entre sua história pessoal e a dos personagens que descreve, como narrador e, ao mesmo tempo, personagem, talvez para que haja um distanciamento e um melhor entendimento de sua atuação.

Esse distanciamento, a mescla de história pessoal com a dos personagens e a presença do real dentro do texto ficcional é o que encontramos, por exemplo, em Os papéis do Inglês, de Ruy Duarte de Carvalho, e em Nove noites, de Bernardo Carvalho.

Em resenha sobre Os papéis do inglês, publicada pela Folha de São Paulo em janeiro de 2001, Bernardo Carvalho afirma que o texto do autor angolano é autorreflexivo e elenca algumas características da narrativa importantes para este trabalho. Primeiro, a escrita para uma destinatária que "se insinua e instala no texto", como o próprio autor explana nas primeiras páginas; depois, merece destaque a busca por respostas para o caso por meio da ficção - o narrador lê o caso da morte do inglês, que é contado à destinatária no livro de crônicas de Henrique Galvão Em terra de pretos - e a criação da própria versão a partir de um sucinto relato.

Outras duas características chamam a atenção: o acúmulo e a sobreposição de histórias, pois os papéis do inglês que são procurados foram herdados pelo avô de um dos informantes do antropólogo que escreve a história e vendidos a um homem branco que, por uma série de coincidências, pode ser o próprio pai do antropólogo; e, finalmente, a encenação da elaboração ficcional em que o romance é construído, não somente pela versão da morte do inglês, mas também pelo processo da busca dos papéis por parte do antropólogo que narra.

Essas estratégias aparecem também no romance Nove noites, de Bernardo Carvalho, publicado em 2002, e são importantes, por exemplo, para analisar a construção dos narradores e a forma como apresentam-nos elementos reais mesclados à ficção. Em 
O retorno do autor e a representação do outro em os papéis do inglês e nove noites Camila da Costa Fonseca - Alfeu Sparemberger

Nove noites, das cartas deixadas por Quain antes do suicídio, uma não é enviada a seu destino. Manoel Perna fala desta carta, tornando sua parte da narrativa, uma espécie de testamento dos fatos para o destinatário, como podemos observar no seguinte trecho:

Passei anos à sua espera, seja você quem for, contando apenas com o que eu sabia e mais ninguém, mas já não posso contar com a sorte e deixar desaparecer comigo o que confiei à memória. Também não posso confiar a mãos alheias o que lhe pertence e durante todos estes anos de tristezas e desilusões guardei a sete chaves, à sua espera (CARVALHO, 2006, p. 6).

Diferente do narrador de Os papéis do inglês, que procura respostas para o suicídio do antropólogo na ficção de Henrique Galvão, em Nove noites o narrador tem o primeiro contato com a história de Quain por meio de um artigo de jornal. Procura, no entanto, responder aos seus questionamentos criando o testemunho de Manoel Perna.

Assim como na narrativa de Ruy Duarte de Carvalho, encontramos em Nove noites a sobreposição de vozes. Embora exista um autor que organiza, a história nos é apresentada como um mosaico de informações que, em algumas passagens, se dizem falsas ou inventadas, como podemos verificar neste trecho, em que o narrador procura pelo filho do fotógrafo em busca de algo que ajude na sua pesquisa:

Àquela altura dos acontecimentos, depois de meses lidando com papéis de arquivos, livros e anotações de gente que não existia, eu precisava ver um rosto, nem que fosse como antídoto à obsessão sem fundo e sem fim que me impedia de começar a escrever meu suposto romance (o que eu havia dito a muita gente), que me deixava paralisado, com medo de que a realidade seria sempre muito mais terrível e surpreendente do que eu podia imaginar e que só se revelaria quando já fosse tarde, com 
O retorno do autor e a representação do outro em os papéis do inglês e nove noites Camila da Costa Fonseca • Alfeu Sparemberger

a pesquisa terminada e o livro publicado. Porque agora eu já estava disposto a fazer dela realmente uma ficção (CARVALHO, 2006, p. 140-141).

Percebe-se que o narrador explica os caminhos percorridos até decidir por escrever uma ficção. Assim como em Os papéis do inglês, em Nove noites algumas passagens mostram a encenação do fazer ficcional, e o leitor tem acesso à tessitura da narrativa e aos receios e à obsessão do narrador pela vida de Quain. Isto pode ser confirmado com a passagem em que o narrador entrevista um casal de antropólogos que estudou e viveu entre os índios Krahô:

Àquela altura, eu já estava completamente obcecado, não conseguia pensar em outra coisa, e como todos os que eu havia procurado antes, eles também não quiseram saber por quê. Ninguém me perguntava a razão. Eu dizia que queria escrever um romance (CARVALHO, 2006, p. 66).

A própria afirmação, ao término da narrativa, de que o relato de Manoel Perna é uma invenção, passa a ser também uma forma de o narrador expor suas escolhas na construção da história de Quain.

\section{A representação do outro e os limites entre ficção e realidade}

Além das características citadas, a criação de ambos os romances tem elementos reais que acabam por confundir o limite entre ficção e realidade, o que geralmente é estabelecido no pacto ficcional. Em Nove noites, por exemplo, temos a inserção de fotos, e alguns dados do narrador coincidem com os do autor, como a profissão de jornalista e o parentesco com o Marechal Rondon. Em Os papéis do inglês as referências à realidade se dão também pela profissão de antropólogo, comum ao narrador e ao autor, e pelos 
O retorno do autor e a representação do outro em os papéis do inglês e nove noites Camila da Costa Fonseca • Alfeu Sparemberger

caminhos percorridos em Angola na busca por informações sobre a morte de Perkings. De acordo com Rita Chaves,

Ruy Duarte realiza uma viagem pelo sul de Angola e pelas décadas que vão do tempo de Galvão à contemporaneidade, referindo fatos do período que ali viveu ele próprio, quando a sua família deslocou-se de Portugal. Foi lá que iniciou o seu percurso por Angola, é para lá que sempre retorna, inclusive para observar Luanda, a capital do país que concentra população, riqueza econômica e poder político e de onde emanam os mandos e desmandos que são objeto de sua atenção (2007).

Os dados referenciais dos romances não são suficientes para que se empreenda uma leitura crendo ingenuamente na realidade, mas também não podem ser desconsiderados. Ao fazer uma interpretação formalista das narrativas, o leitor ignoraria elementos externos que agregam significado e comprometem a compreensão do jogo narrativo que é peculiar a estes textos.

Em entrevista ao crítico literário Flávio Moura, Bernardo Carvalho afirma não fazer distinção entre o real e o ficcional, posto que na narrativa estão mesclados e não é possível separar essas partes:

A indistinção entre fato e ficção faz parte do suspense do romance. Por isso não vejo sentido em dizer o que é real e o que não é. Isso tem a ver com meus outros livros. Também neles há um dispositivo labiríntico, em que o leitor vai se perdendo ao longo da narração. Nesse caso isso fica mais nítido porque existem referências a pessoas reais. Mas mesmo as partes em que elas aparecem podem ter sido inventadas. Em última instância, é tudo ficção (CARVALHO, 2002).

Ainda que o autor de Nove noites afirme que a narrativa não passa de um romance, cabe à crítica e aos leitores a distinção, se 
O retorno do autor e a representação do outro em os papéis do inglês e nove noites Camila da Costa Fonseca - Alfeu Sparemberger

necessário for, do que é real ou verdadeiro, e a atribuição de sentido a isso. Este romance pode ser lido, por exemplo, como uma forma de desestruturar os conceitos de realidade e ficção, de tirá-los de seus lugares comuns para que, juntos, tenham um novo significado. Além disso, mostra novas formas de representação, tanto do outro quanto de nós mesmos.

Na trama criada por Bernardo Carvalho, o narrador tem como foco descobrir "a verdade" sobre a morte do antropólogo Buell Quain. Como as informações que consegue não alcançam a totalidade dos fatos, ele imagina um relato e atribui a função ao personagem real, Manoel Perna, que conviveu com Quain, o que preencheria algumas lacunas. Este personagem, segundo o autor, sofreu mudança de profissão para que sua linguagem fosse verossímil:

\begin{abstract}
Esse personagem, o Manoel Perna, é uma espécie de desejo do autor de resolver as lacunas que não são resolvidas pela pesquisa. Várias pistas me induziam a certas conclusões, mas eu não tinha certeza. Precisava de um negócio que fechasse. E a única pessoa que podia ter visto era ele. Por isso logo no início percebi que ele seria um dos narradores. No livro ele aparece como engenheiro. Na verdade, ele era barbeiro. Mas achei que ia ficar muito inverossímil, ele escrevendo daquele jeito empolado com essa profissão. Foi a única coisa que eu mudei com relação a ele (CARVALHO, 2002).
\end{abstract}

O relato do engenheiro Manoel Perna, que está intercalado no romance com a narrativa principal, é a fonte mais importante na busca pela verdade sobre o antropólogo americano. Essa fonte, no entanto, mostra-se desde o início como incerta, uma vez que, constantemente, o leitor é avisado da precariedade do que é contado: "É preciso estar preparado. Alguém terá que preveni-lo. Vai entrar numa terra em que a verdade e a mentira não têm mais os sentidos que o trouxeram até aqui" (CARVALHO, 2006, p. 6). 
O retorno do autor e a representação do outro em os papéis do inglês e nove noites Camila da Costa Fonseca - Alfeu Sparemberger

Além do relato de Manoel Perna, o narrador tem como fonte as entrevistas realizadas com pessoas que existiram na realidade e fizeram parte da vida de Quain, como Heloísa Alberto Torres, Ruth Landes e Luiz de Castro Faria. Entre as entrevistas, são referidas algumas cartas reais que foram trocadas por estes personagens e Quain, como é possível conferir na pesquisa feita pela Unicamp, em 2008, que une as cartas de campo de Heloísa Alberto Torres ao antropólogo americano.

A inserção dos referidos personagens, por serem conhecidos no ramo da Antropologia, por um lado colabora para dar credibilidade ao que é narrado e, por outro, aumenta a confusão entre o que é real e o que não é, gerada desde o início do romance. Nessa confusão entre o que é real ou não, o que querem os narradores? Por que procuram tanto por informações sobre mortes ocorridas em um tempo tão remoto?

Moraes (2012) afirma que uma série de espelhamentos e contaminações entre os planos narrativos convidam o leitor a associar os próprios narradores às personagens suicidas que são reinventadas: Perkings e Quain. É como se os narradores, ao falar do outro, procurassem lidar consigo mesmos. Assim,

Ambos os romances nos fazem encarar, parece-me, o que há de construção no que tomamos por realidade. Ou melhor: sugerem que, para nos situarmos com relação a nós mesmos e com relação ao outro, recorremos necessariamente a elaborações imaginativas que se aproximam de ficções. Ou seja, lendo esses dois romances, somos convidados a pensar que elaboramos ficções a partir de esquemas ou ordens de representação disponíveis socialmente, sendo a partir dessas "ficções" (pequenas narrativas que construímos a todo o momento) que agimos (inclusive matamos, ou nos matamos). Ao produzir as ficções que deverão representar o que somos e o que os outros são, mobilizamos representações prévias. (MORAES, 2012, p. 159). 
O retorno do autor e a representação do outro em os papéis do inglês e nove noites Camila da Costa Fonseca - Alfeu Sparemberger

Os romances constroem, deste modo, estratégias para expor essa camada, para mostrar a mescla entre imaginação, ficção e realidade. Paralelamente a isso, ocorre a apresentação de cartas, entrevistas, personagens reais e fotografias, como em uma pesquisa. Do mesmo modo, existe a construção de narradores que colocam ao leitor suas histórias pessoais, com memórias de infância e eventos mais atuais dentro do que está sendo contado. Além disso, narram a si mesmos, expondo a tessitura da sua narrativa, como acontece em Os papéis do inglês, quando o narrador declara:

É isso que retenho nos cadernos. Na memória íntima que consigna o registro das minhas emoções, porém, o que retenho não contempla essa margem de apreensão de conhecimento, mas antes a dilatação dos horizontes da minha própria experiência pessoal. (...) Vou ter que contar-me, tratar-me, pois, enquanto personagem dessa estória. E essa então será, comigo a actuar lá dentro e a primeira inscrita nela, a tal estória que tenho para contar-te. E quem narra não há-de ter, ele também que dar-se a contar? Dito assim, dá para entender onde quero chegar? Ou é por demais directo, excessivo, para caber na narração? (CARVALHO, 2007, p. 36).

Dessa forma, o narrador observa as experiências alheias para narrar como lhe convém e também conta sua própria experiência. O autor traz suas pesquisas antropológicas para a ficção, o que faz com que assumam outros papéis. Na narrativa, encontramos muitos elementos, como a construção de um narrador antropólogo que viaja em busca de pistas e a representação do cenário ideológico e do poder no mundo atual.

Além disso, existem também outros papéis, como os que são recuperados pelo autor ao final da narrativa. O romance de Ruy Duarte de Carvalho apresenta intertextualidade ao dialogar uma escrita nova com textos anteriores. De início já encontramos o diálogo com a crônica de Henrique Galvão, que serve de base para a história contada pelo narrador, mas, de acordo com ele próprio, 
O retorno do autor e a representação do outro em os papéis do inglês e nove noites Camila da Costa Fonseca - Alfeu Sparemberger

sua narrativa vai além, respondendo a questões que ficaram pendentes nas versões de Galvão e de Luiz Simões.

Este diálogo entre textos, tempos e espaços, entre as narrativas mais antigas (tradicionais) e a do narrador (moderna), pode ser um caminho para a compreensão de Os papéis do inglês. É possível observar que os papéis e a "verdade" que o narrador tanto procura ficaram sob a tutela do avô de Paulino, o Ganguela do coice, que acompanhava Archibald Perkings e que tem sua importância já desde o título completo do romance: Os papéis do inglês ou o Ganguela do coice.

Assim, o Ganguela-do-coice tinha visto tudo, tinha entendido tudo. E era isso, precisamente, que pelo seu próprio punho, a grosso e tosco, estava escrito no caderno de Archibald: eu vi tudo. Tudo então o que eu poderia ter querido saber dos papéis do Inglês, e dos do meu pai, acabava por cingir-se àquela singeleza de ajustes, e se encerrava assim, ali? (CARVALHO, 2007, p. 176).

Nesta passagem, o narrador mostra-se um tanto decepcionado ao descobrir, pelas anotações do Ganguela, uma verdade que buscou por tanto tempo, e por perceber, também, que era o fim de sua pesquisa. Ele acaba, no entanto, por conformar-se ao compreender que "mais que o achado vale sempre a busca" (CARVALHO, 2007, p. 177).

É importante destacar que, na narrativa de Ruy Duarte de Carvalho, não somente a escrita revela mistérios e tesouros, mas também as experiências e testemunhos orais, como acontece quando Perkings vai à tenda do Ganguela para tocar seu kissange, em um movimento de união entre tradição e modernidade:

Uma importante alteração ao programa viria a dar-se quando, na estação seguinte, o Inglês passou a vir acompanhar, na sanzala, os solos de kissange do Ganguela, surdina morosa em noites de lua e frias, e nos intervalos de alguns trechos mais sentidos era 
O retorno do autor e a representação do outro em os papéis do inglês e nove noites Camila da Costa Fonseca - Alfeu Sparemberger

o lancinante contraponto do stradivarius que vinha dilacerar o peito de tantos homens, de tanta raça e tão sós (CARVALHO, 2007, p. 79).

Além do respeito à experiência que o outro tem a oferecer e do diálogo com outros textos, da mesma forma as características do narrador dialogam em alguns momentos com as do autor. Em Os papéis do inglês, o narrador, que também é personagem, pode ter sua figura confundida com a do autor angolano, mas sua identidade, ainda que tenha pontos em comum, acaba por afastar-se. Se lembrarmos que a versão da morte do inglês feita pelo narrador não é uma cópia fiel do que realmente ocorreu, sua versão de si mesmo na narrativa também criará um ser ficcional. Com a exposição do processo da escrita, o narrador problematiza o que escreve, expõe fontes de leitura e as etapas da sua produção.

Em Nove noites, ao se apresentar, o narrador comunica ao leitor que a narrativa é uma mescla do fruto da sua imaginação com as informações que foi encontrando ao acaso. Percebemos, ao longo da narrativa, que os traços do narrador, como traumas de infância e suas obsessões, acabam por aproximá-lo de Quain, personagem que ele tanto se empenha para recompor na ficção. Ao final do romance, o narrador é até mesmo confundido com Quain pelo fotógrafo que está hospitalizado e que é central para o desfecho da história:

Ele não se mexia, mas chegou a balbuciar algum som, como se quisesse dizer que estava bem, ou pelo menos foi assim que eu o entendi ou quis entender no início: "Well...". Quando fechei a cortina, no entanto, ouvi um nome às minhas costas. Ele me chamava por outro nome. Abri as cortinas e perguntei de novo se precisava de alguma coisa. E ele repetiu o nome. Me chamava "Bill", ou pelo menos foi isso que entendi. Tentava estender o braço na minha direção. Segurei a mão dele. Ele apertou a minha com a força que lhe restava e começou a falar em inglês, com esforço, mas ao mesmo tempo num tom de voz de quem está 
O retorno do autor e a representação do outro em os papéis do inglês e nove noites Camila da Costa Fonseca - Alfeu Sparemberger

feliz e admirado de rever um amigo: “Quem diria? Bill Cohen! Até que enfim! Rapaz, você não sabe há quanto tempo estou esperando" (CARVALHO, 2006, p. 130).

Algumas outras passagens, no início do romance, podem ser lidas como uma busca de si no outro pelo outro, como: "Ou você acha que quando nos olhamos não reconhecemos no próximo o que em nós mesmos tentamos esconder?" (CARVALHO, 2006, p. 8); "É preciso entender que cada um verá coisas que ninguém mais poderá ver. E que nelas residem suas razões. Cada um verá as suas miragens" (CARVALHO, 2006, p. 42).

Em Os papéis do inglês verifica-se também este processo de identificação, quando o narrador acaba por confundir-se com o próprio inglês e sua existência é verificada a partir da existência do outro. Os papéis que são do inglês se tornam também do narrador, uma vez que seu pai os havia comprado do Ganguela e ele os recebe como uma herança. A escrita transforma, assim, "os papéis do inglês" no próprio romance, por serem também do narrador. Essa "con-fusão" entre o narrador e o inglês é encontrada no seguinte trecho:

\begin{abstract}
Quem andava por ali, nessa altura, a cavalgar um land-rover pelas pradarias do Muhunda e do Brutuei? Era eu, bem entendido, mas não o mesmo que está agora a contar-te uma estória. A minha corrida atrás de uns papéis, do meu pai mas que podiam ser também os do Inglês da estória do Galvão, gera a acção que há de resultar uma segunda estória. Será da minha acção enquanto personagem, assim, que resulta essa outra estória que é, afinal, a da minha elaboração da própria estória do Galvão. Vou ter que contar-me, tratar-me, pois, enquanto personagem dessa estória (CARVALHO, 2007, p. 36, grifo do autor).
\end{abstract}

Além desse espelhamento dos personagens com o narrador, algumas passagens reafirmam a confusão entre o que é real ou não ao longo da narrativa. Em Nove noites, por exemplo, em uma 
O retorno do autor e a representação do outro em os papéis do inglês e nove noites Camila da Costa Fonseca • Alfeu Sparemberger

das conversas em que Luiz de Castro fala ao primeiro narrador sobre Quain, é dito que o antropólogo tinha uma obsessão por não revelar sua verdadeira condição e por preservar a realidade da sua vida privada. É interessante perceber a ironia da história da morte desta pessoa, que primava pelo recato, vir à tona em uma narrativa do século 21 , quando a sociedade se importa tanto com as revelações da vida privada.

Em trabalho sobre Bernardo Carvalho, Bruno Oliveira (2010) afirma que Nove noites é uma crítica ao apelo ao real que vivemos na nossa sociedade:

\begin{abstract}
A investigação obsessiva e fracassada do narrador-jornalista em saber o motivo do suicídio de Buell Quain é, em última análise, uma crítica a nossa sociedade midiática, ávida por conhecer a vida das celebridades e interessada sobremaneira pela exposição pública (p. 72).
\end{abstract}

É justamente em razão desta crítica e por não encontrar a verdade dos fatos, que o narrador resolve transformar a sua pesquisa em um texto ficcional. Quando define que o texto será um romance, resolve descobrir o que for possível antes de começar a escrever, temendo que a verdade aparecesse posteriormente à sua produção e a desvalorizasse:

O meu maior pesadelo era imaginar os sobrinhos de Quain aparecendo da noite para o dia, gente que sempre esteve debaixo dos meus olhos sem que eu nunca a tivesse visto, para me entregar de bandeja a solução de toda a história, o motivo real do suicídio, o óbvio que faria do meu livro um artifício risível (CARVALHO, 2006, p. 141).

É baseado nos fatos, que são deduzidos e inventados, que o romance se constrói; é justamente por se tratar de uma ficção que a verdade que foi encontrada poderá ser revelada sem maiores 
O retorno do autor e a representação do outro em os papéis do inglês e nove noites Camila da Costa Fonseca • Alfeu Sparemberger

comprometimentos. "A ficção seria a única realidade possível de ser revelada" (OLIVEIRA, 2010, p. 65). Esta é a forma da já citada crítica ao apelo ao real, comentada pelo próprio Bernardo Carvalho:

\begin{abstract}
Existe uma tendência no mercado que é a de privilegiar os livros que não são ficção, os livros que são alguma coisa real. Romance histórico, por exemplo. Como se o leitor precisasse de uma garantia que vai absorver uma informação útil, que não vai perder tempo viajando na cabeça de um louco. Isso tem a ver com meu livro também. [...] E eu implico um pouco com esse pé no real (2002).
\end{abstract}

O que temos nas narrativas de Ruy Duarte de Carvalho e Bernardo Carvalho é uma modalidade de escrita que vai além da biografia, do texto jornalístico ou mesmo da ficção de uma forma tradicional. O que encontramos nessas narrativas é uma mescla de ficção e etnografia, uma vez que apresentam o já citado "retorno do real", reconfiguram a noção de autor e problematizam a representação do outro e de si mesmos.

Em Nove noites, ainda que o narrador coloque suas experiências na busca pela história de Quain, não é possível representar o outro em sua totalidade, pois este tem um passado que não deixa informações que se possam dizer concretas, por isso ocorre uma invenção de informações. Nessa narrativa, por exemplo, o leitor é "enganado" pelo narrador principal, quando este coloca o relato de Manoel Perna como uma referência na sua investigação da vida de Quain, mas revela, ao final, que o relato foi imaginado.

\title{
4 Literatura e etnografia: a presença do outro
}

Como temos visto até aqui, o "outro" nem sempre pode ser representado, o que faz com que se questione a mescla de ficção e etnografia ou, mais especificamente, o narrador como "etnógra- 
O retorno do autor e a representação do outro em os papéis do inglês e nove noites Camila da Costa Fonseca - Alfeu Sparemberger

fo". De acordo com Klinger (2012), em Nove noites "aparece apenas uma 'contaminação do olhar etnográfico', por exemplo o jornalista de Bernardo Carvalho contando seu estranhamento e incômodo perante os Krahô no Xingu" (p. 117), mas é um equívoco chamar o narrador de "etnógrafo".

Ainda para a mesma autora, já nos anos 80 do século 20, a Antropologia passou a questionar sua autoridade na produção de representações sobre o outro. Começou-se a insinuar, graças às ideias de Clifford Geertz, desenvolvidas em A interpretação das culturas (1989), que a prática etnográfica tinha algo de ficção, pois ele considera os textos antropológicos interpretações, algo construído. Assim, para Geertz,

\begin{abstract}
Os textos antropológicos são eles mesmos interpretações e, na verdade, de segunda e terceira mão. (Por definição somente um "nativo" faz a interpretação em primeira mão: é a sua cultura.) Trata-se, portanto, de ficções; ficções no sentido de que são "algo construído", "algo modelado" - o sentido original de fictio - não que sejam falsas, não-fatuais ou apenas experimentos de pensamento. Construir descrições orientadas pelo ator dos envolvimentos de um chefe berbere, um mercador judeu e um soldado francês uns com os outros em Marrocos de 1912 é claramente um ato de imaginação, não muito diferente da construção de descrições semelhantes de, digamos, os envolvimentos uns com os outros de um médico francês de província, com a mulher frívola e adúltera e seu amante incapaz, na França do século XIX (1989, p. 11, grifos do autor).
\end{abstract}

A ideia de Geertz quanto ao caráter discursivo da disciplina corresponde à segunda virada linguística "pós-moderna" na Antropologia, que veio para desconstruir a primeira virada linguística do estruturalismo. A primeira virada opõe-se à hermenêutica clássica e toma como modelo a estrutura da linguagem elaborada por Saussure. 
O retorno do autor e a representação do outro em os papéis do inglês e nove noites Camila da Costa Fonseca - Alfeu Sparemberger

O referido modelo inspirou o protótipo da antropologia estruturalista proposta por Lévi-Strauss, no qual os fenômenos de parentesco somente têm significação se forem integrados em sistemas que vão responder a leis gerais, porém ocultas. O estruturalismo de Saussure previa condições estáveis de verificabilidade dos fenômenos dentro do conhecimento lógico-científico; trabaIhava com a língua e não com a fala, pois esta não era passível de formalização sistemática, sincrônica e abstrata.

Segundo Ítalo Moriconi (1994), houve um declínio do estruturalismo como paradigma transdisciplinar nos anos 70 do século 20. O que se abandonou não foi a ideia do sociocultural, que se distingue pelo caráter simbólico de linguagem, mas a crença na formalização de regras universais de formação de sentido. No final da década de 70, houve um total desinteresse pela Linguística e pela Semiologia enquanto ciências positivas, e passou-se a dar atenção às filosofias analíticas e hermenêuticas da linguagem, uma vez que elas se preocupavam com as relações entre os interlocutores como fonte de sentido para a linguagem.

Dessa forma, a antropologia elaborada por Geertz é pós-estruturalista, pois retoma o sujeito, anulado pelo pensamento estruturalista, sem propor a volta do sujeito ingênuo da hermenêutica clássica. Logo, a segunda virada da etnografia nega a existência de um núcleo de sentido, afirmando que isso se dá no jogo de interpretações em que o sujeito e o objeto modificam um ao outro. Conforme Moriconi,

[...] ao jogo de pensamento na modernidade, polarizado pela relação de conhecimento entre sujeito e objeto, propõe-se a alternativa do jogo pós-moderno de intersubjetividade, da relação entre eu e outro como parceiros no diálogo (1994, p. 64).

Esse "fim" do estruturalismo e da separação entre sujeito e objeto é um ponto importante para a Antropologia pós-moderna. Em consonância com as filosofias da linguagem, que consideram nosso conhecimento sobre o mundo não factual, mas linguístico, e 
O retorno do autor e a representação do outro em os papéis do inglês e nove noites Camila da Costa Fonseca - Alfeu Sparemberger

também uma expressão de definições ou das consequências dessas definições, a Antropologia pós-moderna considera que o outro existe como sua representação. Isso implica em uma crise no conceito de representação, uma vez que desvincula o pensamento e a criação de sua relação com o real no sentido estruturalista.

$\mathrm{Na}$ Antropologia, a segunda virada linguística é autorreflexiva. Não é apenas um metadiscurso acerca da Antropologia, mas um retorno do sujeito como efeito de produção de sentido. Com as ideias de Clifford Geertz, passou-se a questionar a autoridade da Antropologia que, desde o trabalho de campo de Bronislaw Malinowski e Franz Boas, era baseada na experiência.

Segundo Geertz (1991), ao longo da história da antropologia o conceito de experiência sofreu modificações. No início, a disciplina tinha como base as narrações de terras distantes dos viajantes europeus dos séculos 15 ao 18. Etnografia e antropologia possuíam atividades diferentes até o século 19 , sendo a primeira a coleta de dados e a segunda com análise e produção escrita. Esta retomada histórica foi feita por Diana Klinger no livro Escritas de si, escritas do outro: o retorno do autor e a virada etnográfica (2012), no capítulo em que estudou a crise da representação na virada etnográfica.

O texto de Klinger, aliás, foi de suma importância para o presente estudo, que teve inclusive parte de seu subtítulo incorporado ao título deste. Ainda no mesmo capítulo, Klinger afirma que, após o auge do estruturalismo e do marxismo, e da projeção que ganhou a Antropologia nos anos 60 e 70, a disciplina vivenciou um período de crise nos anos 80 e passou-se a duvidar da possibilidade de desenvolver-se uma antropologia científica. Assim, como dito anteriormente, com Geertz a antropologia torna-se interpretativa, deixando de ser experimental.

Em A interpretação das culturas (1973), Geertz define a cultura como união de textos, como rede de significados. A tarefa do etnógrafo é a descrição densa, realizada nos moldes da interpretação filológica. O etnógrafo deve interpretar o exótico e descobrir os significados do que é turvo e estranho. 
O retorno do autor e a representação do outro em os papéis do inglês e nove noites Camila da Costa Fonseca - Alfeu Sparemberger

De outra parte, cabe lembrar que Hal Foster compreende o paradigma do artista como etnógrafo semelhante, na estrutura, ao "autor como produtor", de Benjamin. Nestes modelos, o autor identifica-se com o outro e a diferença é uma passagem do sujeito, que é definido em termos econômicos, para um fixado por sua diferença cultural, ou seja, existe uma apropriação do outro. Para Klinger, a diferença entre os modelos de narrador propostos por Benjamin e Foster e o narrador etnográfico se dá em outro aspecto:

O modelo etnográfico definido por Foster ainda implica (como no paradigma de Walter Benjamin) a postulação de uma relação entre a transformação artística e a transformação política, e a ideia de que as possibilidades de transformação estão localizadas no campo do "outro" (2012, p. 118).

Assim, nos dois modelos o autor corre o risco de crer que o outro, "primitivo", tem acesso especial à psique primária, nele estando a verdade da natureza selvagem do homem. O primitivo seria, ao mesmo tempo, um estágio primário da cultura do indivíduo e também do seu desenvolvimento. Este outro, para o modelo de Foster, tem como base a antropologia tradicional e é passível de representação.

Nos moldes da antropologia tradicional, a etnografia seria observação e análise da vida de grupos humanos diferentes do nosso, pela restituição com a maior fidelidade possível da vida destes grupos. Em Os papéis do inglês, por exemplo, o narrador monta um perfil para o personagem Archibald Perkings, e o coloca como um antropólogo que trabalha com a antropologia social na Universidade de Londres, mas que se vê em um contexto em que a visão colonialista impera. Para Perkings, “o conhecimento dos antropólogos deveria aproveitar então à mudança integrada e não à redutora domesticação do indígena" (CARVALHO, 2007, p. 50), mas sua proposta de romper com os paradigmas do pensamento colonial não é aceita, o que o aborrece muito. Nessa época, início do século 20, a atenção dos antropólogos, 
O retorno do autor e a representação do outro em os papéis do inglês e nove noites Camila da Costa Fonseca - Alfeu Sparemberger

munida de um capital de conhecimento iluminado pelo evolucionismo e pela perspectiva difusionista, deveria era assentar-se ao passado. E mesmo Radcliff-Brown, que pugnava pela atenção às sociedades instaladas no seu presente, estava ainda a ver só nessas mesmas sociedades um mero objeto exposto à observação dos sábios (CARVALHO, 2007, p. 51).

Para a antropologia pós-moderna e para os narradores de Os papéis do inglês e Nove noites, porém, não é possível falar do outro com a fidelidade esperada, pois estas narrativas dobram-se sobre si próprias de forma autorreflexiva. Na antropologia pós-moderna, os textos etnográficos mostram fenômenos que não são observados de fora, mas compreendidos a partir da participação e da experiência daquele que escreve, mostrando a si próprio como uma construção.

Esta exposição da experiência individual do autor e a ilusão de identidade entre autor e narrador geram um conflito de representação que aproxima as narrativas de Ruy Duarte e Bernardo Carvalho não de um relato etnográfico tradicional, mas, sim, pós-moderno. Em Os papéis do ing/ês, o narrador descreve sua experiência na busca pelos papéis e as relações que faz ao longo do percurso; em Nove noites percebemos não somente o foco no outro, mas também no eu que narra.

Essas características correspondem à antropologia pós-moderna, na qual ocorre, de acordo com Klinger, a "Dissolução da polaridade eu/outro: o terreno criado pela etnografia pós-estruturalista não é mais um campo dominado pelo outro (como no modernismo e na antropologia clássica), e, sim, pela noção de diferença que supõe a mútua projeção (2012, p. 119).

A noção de diferença e a mútua projeção são encontradas, por exemplo, em Nove noites, quando o narrador vai até os índios Krahô para investigar o suicídio de Quain e acaba sendo interrogado e intimidado por um dos índios: 
O retorno do autor e a representação do outro em os papéis do inglês e nove noites Camila da Costa Fonseca • Alfeu Sparemberger

Leusipo perguntou o que eu tinha ido fazer na aldeia. Preferi achar que o tom era amistoso e, no meu paternalismo ingênuo, comecei a Ihe explicar o que era um romance. Ele não estava interessado. Queria saber o que eu tinha ido fazer na aldeia. Os velhos estavam preocupados, queriam saber por que eu vinha remexer no passado, e ele não gostava quando os velhos ficavam preocupados. Eu tentava convencê-lo de que não havia motivo para preocupação. Tudo o que eu queria saber já era conhecido. [...] Ele seguia incrédulo. Fazia-se de desentendido, mas na verdade só queria me intimidar. Eu estava entre irritado e amedrontado (CARVALHO, 2006, p. 85).

Além do contato fracassado com os índios na busca por informações sobre Quain, o narrador conta as histórias de viagens de sua infância e de quando esteve no Xingu com seu pai. Essas viagens ao Xingu também foram feitas pelo autor de Nove noites, que tem sua identidade, em muitas passagens, mescladas com a do narrador.

\section{Considerações finais}

Além da procura pela verdade sobre a misteriosa morte de antropólogos e de jogar com a realidade e a ficção, Os papéis do inglês e Nove noites têm outros dois pontos em comum que conformam características da narrativa contemporânea: possuem narradores que fazem uso da primeira pessoa, desenvolvendo um olhar sobre o outro, que é diferente culturalmente, e também sobre si mesmos, manipulando histórias reais mescladas com suas próprias memórias. Esse tipo de escrita está presente no âmbito do chamado "retorno do autor" e na chamada "virada etnográfica".

Antes, porém, do "retorno do autor", como vimos, foi decretada a "morte do autor", quando o Formalismo Russo e o Estruturalismo não consideraram a figura autoral como elemento de análise. Ainda assim, Michel Foucault (1992) reconheceu a necessidade de 
O retorno do autor e a representação do outro em os papéis do inglês e nove noites Camila da Costa Fonseca • Alfeu Sparemberger

preenchimento do espaço deixado pela figura do autor, propondo uma substituição a partir do que denominou de "função autor". Roland Barthes também defendia a tese da morte do autor, mas reconhecia sua presença em diversos meios, como entrevistas de jornais, biografias ou manuais de história literária.

A preocupação da crítica estruturalista naquele momento era defender uma modalidade que excluísse os aspectos biográficos e se detivesse unicamente ao texto. Esse reconhecimento da presença dos autores em espaços midiáticos, de acordo com Barthes, faz com que se questione se a literatura do início do século 21 admitiria essa morte do autor e a exclusão de aspectos biográficos ou referenciais da ficção. De certo modo, é nesse contexto de aparição no espaço público midiático que se dá o retorno do autor, quando o leitor anseia por conhecê-lo, e também seu contexto de produção e seus objetos pessoais; assim, ele deixa de ser um simples nome na capa do livro, passando a ser acessível ao público.

Os romances aqui estudados podem ser considerados, então, pós-etnográficos, por sua natureza pós-moderna, uma vez que se constroem entre o ficcional e o real, entre o relato da observação do outro e a vivência autobiográfica e o relato de si. Assim, foi possível pensar a relação dos narradores e dos autores com a escrita do outro e de si mesmos, além das situações em que se colocam como personagens e participam do enredo. Nesta medida, estão lado a lado com o outro, que é observado e representado, gerando outra matéria para o relato: a das experiências e impressões subjetivas dessa convivência.

\section{Referências}

BENJAMIN, Walter. "O narrador". In: BENJAMIN, Walter. Magia e técnica, arte e política. São Paulo: Brasiliense, 1985. (Obras Escolhidas, v. 1). 
O retorno do autor e a representação do outro em os papéis do inglês e nove noites Camila da Costa Fonseca • Alfeu Sparemberger

CARVALHO, Bernardo. Nove noites. São Paulo: Companhia das Letras, 2006 [2002].

CARVALHO, Ruy Duarte de. Os papéis do inglês. São Paulo: Companhia das Letras, 2007.

CHAVES, Rita. "Os papéis do inglês, de Ruy Duarte de Carvalho". In: Carta maior [on-line]. 6/6/2007. Disponível em: http://cartamaior.com.br/?/Editoria/Midias/Os-papéis-do-inglês-de-RuyDuarte-de-Carvalho-/12/13341. Acesso em: 25 jun. 2017.

DOUBROVSKY, Serge. "O último eu”. In: NORONHA, Jovita Maria Gerheim (Org.). Ensaios sobre a autoficção. Belo Horizonte: Ed. UFMG, 2014. p. 111-125.

FOUCAULT, Michel. O que é um autor? Lisboa: Passagens, 1992. GEERTZ, Clifford. A interpretação das culturas. Rio de Janeiro: LTC, 1989 [1973].

KLINGER, Diana. Escritas de si, escritas do outro: o retorno do autor e a virada etnográfica. 2. ed. Rio de Janeiro: 7 Letras, 2012. MARCUSE, Herbert. A dimensão estética. Portugal: Edições 70, 2007.

MORAES, Anita Martins Rodrigues de. “Ficção e etnografia: o problema da representação em Os papéis do inglês, de Ruy Duarte de Carvalho, e Nove noites, de Bernardo de Carvalho". In: Via Atlântica. São Paulo, n. 21, p. 155-172, jul. 2012.

MORICONI, Ítalo. A provocação pós-moderna. Razão histórica e política da teoria de hoje. Rio de Janeiro: Diadorim, 1994.

OLIVEIRA, Bruno. A autoficção no campo da escrita de si: a construção do mito do escritor em Nove noites, de Bernardo de Carvalho, e outros procedimentos autoficcionais na prosa brasileira contemporânea. 2010. 111 f. Dissertação (Mestrado) - Universidade Estadual do Rio de Janeiro, Uerj, Rio de Janeiro, 2010. Disponível em: http://livros01.livrosgratis.com.br/cp 132130.pdf. Acesso em: jun. 2017. 